\title{
Diversity of Brazilian Fungi
}

Leonor C. Maia, Aníbal A. de Carvalho Júnior ${ }^{1}$, Laise de H. Cavalcanti, Adriana de M. Gugliotta, Elisandro R. Drechsler-Santos, André L.M. de A. Santiago, Marcela E. da S. Cáceres, Tatiana B. Gibertoni, André Aptroot, Admir J. Giachini, Adriene M. da S. Soares, Allyne C.G. Silva, Altielys C. Magnago, Bruno T. Goto, Carla R.S. de Lira, Carlos A.S. Montoya, Carmen L.A. Pires-Zottarelli, Danielle K.A. da Silva, Dartanhã J. Soares, Diogo H.C. Rezende, Edna D.M.N. Luz, Emerson L. Gumboski, Felipe Wartchow, Fernanda Karstedt, Fernando M. Freire, Flávia P. Coutinho, Georgea S. N. de Melo, Helen M. P. Sotão, luri G. Baseia, Jadergudson Pereira, Jadson J.S. de Oliveira, João F. Souza, José L. Bezerra, Lídia S. Araujo Neta, Ludwig H. Pfenning, Luís F.P. Gusmão, Maria A. Neves, Marina Capelari, Melissa C.W. Jaeger, Melissa P. Pulgarín, Nelson Menolli Junior, Priscila S. de Medeiros, Raquel C.S. Friedrich, Renata dos S. Chikowski, Ricardo M. Pires, Roger F. Melo, Rosa M.B. da Silveira, Salomé Urrea-Valencia, Vagner G. Cortez \& Valéria F. da Silva.

\begin{abstract}
Knowledge about the Brazilian fungal diversity was, until 2010, recorded in few taxonomy and ecology publications, as well as in a handful of species lists. With the publication of the Catálogo de Plantas e Fungos do Brasil and the continued availability of an online list, it has been possible to aggregate this dispersed knowledge. The version presented here adds 2,111 species names to the 3,608 listed in 2010. A total of 5,719 species of fungi distributed in 1,246 genera, 102 orders and 13 phyla represents a considerable increase over the last five years, when only 924 genera and 78 orders were registered. Basidiomycota (2,741 species in 22 orders) and Ascomycota (1,881 species in 41 orders) predominate over other groups. The Atlantic Rainforest has the largest number of records, with 3,017 species, followed by Amazon Rainforest (1,050), Caatinga (999), Cerrado (638) and Pampa and Pantanal with 84 and 35 species, respectively. The Northeast region has the greatest richness (2,617 species), followed by Southeast $(2,252)$, South (1,995), North $(1,301)$ and Central-West (488 species). Regarding the States of the Federation, São Paulo with 1,846 species, Pernambuco with 1,611 and Rio Grande do Sul with 1,377 species are the most diverse.

Key words: Taxonomy, mycology, brazilian regions.

\section{Resumo}

Até 2010, o conhecimento sobre a diversidade de fungos do Brasil estava registrado em publicações esparsas de taxonomia e ecologia e em algumas poucas listas de espécies. Com a publicação do Catálogo de Plantas e Fungos do Brasil, e a disponibilização da lista online, tem sido possível agregar o conhecimento disperso. A versão ora apresentada acrescenta 2.111 nomes de espécies aos 3.608 listados em 2010. São citadas 5.719 espécies de fungos distribuídas em 1.246 gêneros, 102 ordens e 13 divisões, consistindo em considerável aumento em relação a 2010, quando estavam registrados 924 gêneros e 78 ordens. Predominam os Basidiomycota (2.741 espécies, em 22 ordens) e Ascomycota (1.881 espécies, em 41 ordens). A Mata Atlântica possui a maior quantidade de registros, com 3.017 espécies, seguido pela Amazonia (1.050), Caatinga (999), Cerrado (638) e Pampa e Pantanal com 84 e 35 espécies, respectivamente. A região Nordeste tem a maior riqueza (2.617 especies), seguida pelo Sudeste (2.252), Sul (1.995), Norte (1.301) e Centro Oeste (488 espécies). Em relação aos Estados da Federação, São Paulo (1.846 espécies), Pernambuco (1.611) e Rio Grande do Sul (1.377) são os mais diversos.

Palavras-chave: Taxonomia, micologia, regiões brasileiras.
\end{abstract}




\section{Introdução}

The publication of the Catálogo de Plantas e Fungos do Brasil (Forzza et al. 2010) was possible due to the voluntary participation of experts from various areas of Botany and Mycology. The catalogue constitutes a milestone in the systematization and dissemination of data on the diversity registered in Brazil. Besides the plants, organisms belonging to the kingdom Fungi (Ascomycota, Basidiomycota, Blastocladiomycota, Cryptomycota, Chytridiomycota, Entomophtoromycota, Glomeromycota and Zygomycota) and others, such as Hyphochytridiomycota, Labirinthulomycota, Myxomycota, Oomycota and Plasmodiophoromycota, currently classified in other kingdoms but traditionally studied by mycologists, have been treated and cited as Fungi sensu lato (Maia \& Carvalho Jr 2010).

The history of Brazilian mycology was described by Fidalgo (1968), who demonstrated that in the early stages of this discipline, the main collectors of the country's fungi were foreigners who sent material to be identified abroad. Among these, the best known are Montagne, Hennings, Bresadola and Rick, the latter considered the 'Father of Brazilian Mycology', due to his great contribution in this field. Arriving in Brazil in 1903, Rick initially asked for help from his foreign colleagues, sending specimens to herbaria outside, but from 1929 the collected material was studied and deposited in Brazilian herbaria, especially at the Anchieta herbarium (PACA), which has a fungal collection with around 13,000 specimens (Fungi Rickiani).

After 1930, the situation changed and some isolated initiatives for knowledge of the country's fungi were published by researchers such as Viégas that, after 1930, released a series of papers on plant pathogenic fungi (Viégas 1939, 1940, 1943, 1944, 1945, 1946). Viégas better known work is the Index of Fungi of South America (Viégas 1961). Other important contributions came from Chaves Batista and colleagues, who published in the 1960s and 1970s more than 700 papers listed in Silva \& Minter (1995) that are mostly available online (http://batista. fungibrasil.net/). After that, a list of Myxomycetes in São Paulo was provided by Hochgesand \& Gottsberger (1996).

Prior to the Catálogo de Plantas e Fungos do Brasil (Forzza et al. 2010), but already within this century, Góes Neto \& Cavalcanti (2002) and Cavalcanti et al. (2006) presented respectively lists of Myxomycetes in the states of Bahia and
Piauí; Cavalcanti (2002), Maimoni-Rodella (2002) and Putzke (2002) listed Myxomycetes occurring in different regions of the country; Curvo (2006) provided a list of fungi from Mato Grosso; Mendes et al. $(1998,2010)$ presented a list of species of fungi on plants in Brazil; Maia et al. (2002) showed the diversity of fungi in Pernambuco; Hennen et al. (2005) provided a catalogue of Brazilian rusts (Pucciniales); Gusmão \& Maia (2006) showed the diversity of fungi in the semi-arid; Milanez et al. (2007) published a list of zoosporic fungi of Brazil; Maia et al. (2007) discussed the representation of fungi in Brazilian herbaria. Several lists on Agaricomycetes were also published: species in Brazil (Putzke 1994), in the Amazon Rainforest (Silva \& Gibertoni 2009), in the Atlantic Rainforest (Baltazar \& Gibertoni 2009), in the semiarid (Drechsler-Santos et al. 2009) and in the Cerrado (Gibertoni \& Drechsler-Santos 2010). These publications considered specific groups (eg, plant parasitic) or focused on the diversity of fungi in some regions or states of the federation.

Since Maia \& Carvalho Jr. (2010), several articles were published, new listings were made available and more contributors continued to systematize information in the on-line database of the Brazilian List, which was open to improvement. Among these publications, included or not in the database, we found some related to: Pucciniales (Carvalho Jr. \& Hennen 2010, 2012; Salazar-Yepes \& Carvalho Jr. 2010a, b, 2012, 2014); conidial fungi, with new genera, species and records for Brasil (Almeida et al. 2011, 2014; Barbosa \& Gusmão 2011; Izabel et al. 2011; Cruz et al. 2012; Almeida et al. 2013; Barbosa et al. 2013; Fiuza et al. 2014; Monteiro \& Gusmão 2013; Monteiro et al. 2014a, b); Ingoldian fungi (Fiuza \& Gusmão 2013a, 2013b; Fiuza et al. 2015), zoosporic fungi (Nascimento et al. 2012; Jesus et al. 2013), new species and records of Myxomycetes (Alves et al. 2010; Bezerra et al. 2010, 2014; Bezerra \& Cavalcanti 2010; Silva \& Cavalcanti 2010; Costa et al. 2011, 2014; Damasceno et al. 2011; Silva \& Cavalcanti 2012; Parente \& Cavalcanti 2013; Cavalcanti et al. 2014, 2015), new species and records of Zygomycota (Santiago et al. 2011a, b, 2013, 2014; Souza et al. 2012, 2014); new orders, families, genera, species, recombinations and review in Glomeromycota (Goto et al. 2011, 2012, 2013; Mello et al. 2012, 2013; Oehl et al. 2011a, b; Pontes et al. 2013), including phylogenetic studies of Gigasporales (Silva et al. 2013). In Ascomycota: new genus 
and species of histeriaceous fungi (Almeida et al. 2014), generic reviews of: Ascobolus and Saccobolus (Melo et al. 2014), Diorygma (Feuerstein et al. 2014), Polymeridium (Aptroot \& Cáceres 2014c); new genera: Anabahusakala (Carmo et al. 2014); Helicodochium (Monteiro et al. 2014a); Ypsilomyces (Almeida \& Gusmão 2014); Ellisembiopsis (Izabel et al. 2013); Anacraspedodidymum (Silva et al. 2014); new records, genera and species of liquenized fungi (Alves et al. 2014; Aptroot et al. 2013; Aptroot \& Cáceres 2014a, b; Cáceres et al. 2012, 2013; Feuerstein et al. 2014; Lima et al. 2013a, b; Menezes et al. 2013). In Basidiomycota: new species and records of Agaricomycetes (Abrahão et al. 2012; Baltazar et al. 2012; Cabral et al. 2012; Coimbra \& Gibertoni 2015; Coimbra et al. 2012, 2013; Cortez et al. 2011; Drechsler-Santos et al. 2012a, b, c, 2013; Gibertoni et al. 2012; Gomes-Silva et al. 2012, 2013, 2014; Sá et al. 2014; Soares et al. 2014; TrierveilerPereira et al. 2011; Wartchow et al. 2013a, b), as well as approaches to some genera: Coltricia (Baltazar et al. 2010), Phellinus and Inonotus (Baltazar \& Gibertoni 2010), Trichaptum (Gibertoni et al. 2011), Diplomitoporus (Baltazar et al. 2013), Pleurotus (Menolli Jr. et al. 2014), Henningsia (Gibertoni \& Ryvarden 2014), among others.

After 2010, some checklists were also published, including: Glomeromycota of the Caatinga (Maia et al. 2010) and semiarid region (Goto et al. 2010); Agaricomycetes of the Cerrado (Gibertoni \& Drechsler-Santos 2010; Abrahão et al. 2012); fungi of the Serra da Jibóia, Bahia (Barbosa et al. 2014); coprophilous fungi (Calaça et al. 2014) and a book on macrofungi of the semiarid region (Neves et al. 2013).

In recent years the taxonomic placement of fungi has undergone major changes, especially after the work of Hibbett et al. (2007), with more than 60 colleagues, who proposed a phylogenetic classification for the kingdom. Throught the use of this new approach, the classification of many groups of fungi changed at different taxonomic levels. These analyses accelerated the discovery of new genera and species, creating new families, rearrangement of orders, classes and phyla in an attempt to group taxa phylogenetically to produce a more consistent classification. In this context, the listing process also involves vastly updating the nomenclature of species and moving them to their current position, which involves extra work. Taking as example the Glomeromycota, a phylum proposed by Schüssler et al. (2001) to include only arbuscular mycorrhizal fungi, which were previously included in Zygomycota.
In 2001 this group was divided into four orders and seven families, comprising about 150 species; today the phylum is represented by three classes, five orders, 15 families and 38 genera, with more than 250 species, of which 157 occur in Brasil. Among these, more than 20 were originally described from material collected in Brazil (Goto et al. 2011, 2012, 2013; Mello et al. 2012, 2013; Marinho et al. 2014). Another significant change occurred in Zygomycota, disregarded for being polyphyletic (Hibbett et al. 2007). The species formerly placed in this group are currently classified in Entomophthoromycota (Humber 2012) and four subphyla of uncertain position: Mucoromycotina, Zoopagomycotina, Kickxellomycotina and Mortierellomycotina (Hibbet et al. 2007; Hoffmann et al. 2011). However, considering that the subphylum category was not included in the present work, part of the species of the group were kept in the previously considered phylum Zygomycota, while the rest is included in Entomophthoromycota. This information shows how quickly the classifications have changed and how the new findings contribute to our work, considering the wealth of fungal species yet to be unveiled.

\section{Methodology}

The method used in this study was the same adopted in Forzza et al. (2010) and Maia \& Carvalho Jr. (2010), and the work was improved by invited experts who used the on-line database available at the web page of Jardim Botânico do Rio de Janeiro. Each expert had the task of including new records and modifying data from previous records, in the light of the latest knowledge to their speciality group. The coordinators of the group of fungi were tasked with reviewing and complementing data which eventually have not been filled in by the specialists. The dataset finalized in March 2015, was used to prepare the present analyses, and can be found at the Brazilian List of Fungi sensu lato (see supplementary material $<\mathrm{http}$ // dx.doi.org/10.6084/m9.figshare.1538651> - DOI: $10.1590 / 2175-7860201566407)$. Only the checked and accepted names of fungi with the respective authors were used as base for inclusion of data in the present article. Due to the work required, this review was not complete although most of the data have been included.

Experts that contributed to this data collection, listed in alphabetical order of the first author: Aptroot, A. (Ascomycota-Acarosporales, Baeomycetales, Lichinales, Mycocaliciales); Aptroot, A., Cáceres, 
M. (Ascomycota-Arthoniales, Candelariales, Ostropales, Peltigerales, Pertusariales, Pyrenulales, Teloschistales, Trypetheliales, Verrucariales); Aptroot, A., Gumboski, E.L., Cáceres, M. (Ascomycota-Lecanorales); Baseia, I.G., Cortez, V.G. (Basidiomycota-Geastrales, Hysterangiales, Phallales); Bezerra, J.L. (AscomycotaHelotiales, Pezizales); Bezerra, J.L., Soares, D.J. (Ascomycota-Meliolales, Rhytismatales); Bezerra, J.L., Soares, D.J., Aptroot, A., Coutinho, F., Melo, R.F. (Ascomycota-Dothideales); Bezerra, J.L., Soares, D.J., Pfenning, L. (AscomycotaPhyllachorales); Bezerra, J.L., Soares, D.J., Pfenning, L., Drechsler-Santos, E.R., Palácio, M., Freire, F.M., Friedrich, R.C.S., Gusmão, L.F.P. (Hypocreales); Cáceres, M. (Ascomycota-Incertae sedis); Capelari, M., Cortez, V.G., Neves, M.A., Baseia, I.G., Wartchow, F., Menolli Júnior, N., Karstedt, F., Oliveira, J.J.S., Urrea-Valencia, S. (Basidiomycota-Agaricales); Carvalho Jr., A. A. de (Basidiomycota-Urocystidiales); Carvalho Jr., A. A. de, Sotão, H.M.P. (Basidiomycota-Pucciniales), Cavalcanti, L.H. (Myxomycota-Ceratiomyxales, Echinosteliales, Liceales, Physarales, Stemonitales, Trichiales); Bezerra, J.L., Coutinho, F. (AscomycotaAsterinales, Microthyriales); Drechsler-Santos, E.R., Melo, G.S.N., Palácio, M., Gomes-Silva, A.C. (Basidiomycota-Gloeophyllales); Giachini, A., Silveira, R.M.B., Drechsler-Santos, E.R. (Basidiomycota-Gomphales); Gibertoni, T.B., Gomes-Silva, A.C., Chikowski, R.S., Lira, C.R.S., Soares, A.M.S., Melo, G.S.N., Araújo Neta, L., Gugliotta, A.M., Medeiros, P.S.,Silva, V.F., Silveira, R.M.B., Drechsler-Santos, E.R., Montoya, C.A.S. (Basidiomycota-Hymenochaetales) Gibertoni, T.B., Neves, M.A., Wartchow, F., Chikowski, R.S., Silveira, R.M.B. (Basidiomycota-Cantharellales); Goto, B.T., Maia, L.C. (GlomeromycotaParaglomerales), Goto, B.T., Maia, L.C., Silva, D.K.A. (Glomeromycota-Archaeosporales, Diversisporales, Glomerales); Gugliotta, A.M., Gibertoni, T.B., Drechsler-Santos, E.R., Silveira, R.M.B., Chikowski, R.S., Pires, R.M., Montoya, C.A.S., Souza, J.F., Palácio, M., Rezende, D.H.C. (Basidiomycota-Polyporales); Gumboski, E. L. (Ascomycota-Lecanorales); Gusmão, L.F.P., Melo, R. (Ascomycota-Sordariales); Gusmão, L.F.P., Pfenning, L. (Incertae sedis); Neves, M.A., Magnago, A.C. (BasidiomycotaBoletales); Neves, M.A., Gibertoni, T.B., Jaeger, M.C.W., Melo, G.S.N., Gomes-Silva, A.C., Araújo Neta, L., Wartchow, F., Chikowski, R.S.,
Silveira, R.M.B. (Basidiomycota-Russulales); Pfenning, L., Gusmão, L.F.P. (AscomycotaEurotiales); Pereira, J. (Ascomycota-Xylariales); Pires-Zottarelli, C.L.A. (HyphochytriomycotaHyphochytriales; LabyrinthulomycotaThraustochytriales; Oomycota-Albuginales, Haptoglossales, Incertae sedis, Leptomitales, Myzocytiopsidales, Olpidiopsidales, Pythiales, Rhipidiales, Rozellopsidales, Saprolegniales; Plasmodiophoromycota-Plasmodiophorales; Blastocladiomycota-Blastocladiales; Chytridiomycota-Chytridiales, Incertae sedis, Lobulomycetales, Monoblepharidales, Rhizophlyctidales, Spizellomycetales; Cryptomycota); Pires-Zottarelli, C.L.A., Luz, E.D. (Oomycota-Peronosporales); Santiago, A.L.C.. (Entomophthoromycota-Entomophthorales; Zygomycota-Dimargaritales, Endogonales, Mortierellales, Mucorales, Zoopagales); Silva, D.K.A., Silva, G.A., Maia, L.C. (GlomeromycotaGigasporales); Silveira, R.M.B. (BasidiomycotaAtheliales, Auriculariales, Corticiales, Thelephorales); Soares, D.J., Coutinho, F., Melo, R.F. (Ascomycota-Capnodiales, Diaporthales, Erysiphales, Doassansiales); Soares, D.J., Coutinho, F., Melo, R.F., Gusmão, L.F.P. (AscomycotaPleosporales).

Considering that information on distribution of the occurrence and research in the various biomes and Brazilian ecosystems is still insufficient, it was impossible to determine with certainty which species were endemic and threatened taxa; therefore this aspect was not addressed in this study.

\section{Results \& Discussion}

From Maia \& Carvalho Jr. (2010), there has been gradual increase in the number of fungal species registered, that culminated with the complete dataset found at the Brazilian List of Fungi sensu lato (see supplementary material $<\mathrm{http}$ :// dx.doi.org/10.6084/m9.figshare.1538651> - DOI: $10.1590 / 2175-7860201566407)$. There is a greater increase in the contribution of species records between the years 2010 and 2015. In 2010, 3,608 species were recorded and until of 2015, more 2,111 species, reaching a final count of 5,719 species names were added to this new version.

Species of Basidiomycota (2,741 species) and Ascomycota $(1,881$ species) predominated in the current list (Tab. 1) as was expected given that these are the two major groups of fungi, respectively with more than 30 and 60 
Table 1 -Number of fungal species, by phylum, registered in the Brazilian List of Plants and Fungi in 2010 and 2015.

\begin{tabular}{lcc}
\hline Phylum & Number of fungal species \\
\hline Basidiomycota & $\mathbf{2 0 1 0}$ & $\mathbf{2 0 1 5}$ \\
Ascomycota & 1730 & 2741 \\
Incertae sedis & 1134 & 1881 \\
Myxomycota & 34 & 261 \\
Oomycota & 216 & 234 \\
Glomeromycota & 193 & 196 \\
Chytridiomycota & 109 & 157 \\
Zygomycota & 112 & 111 \\
Blastocladiomycota & 85 & 98 \\
Cryptomycota & 17 & 17 \\
Entomophthoromycota & 0 & 5 \\
Hyphochytriomycota & 4 & 5 \\
Labyrinthulomycota & 4 & 5 \\
Plasmodiophoromycota & 4 & 4 \\
\hline
\end{tabular}

thousand species already described (Kirk et al. 2008). For other phyla, the number of species described worldwide is very low, ranging from less than 30 (Hyphochytridiomycota) to about 1,100 (Chytridiomycota, Myxomycota, Oomycota and Zygomycota, for example). In the range of 50 to 250 species are the Labirinthulomycota (48), Plasmodiophoromycota (47) and Glomeromycota (250). The representativeness of these phyla in Brazil is not fully known, neither is Ascomycota and Basidiomycota, but almost the totality of what was recorded in the country for these smaller groups is now listed. Of the 250 species of Glomeromycota in the world, for example, 157 are cited for Brazil, which represents approximately $66 \%$ of the total, but for some groups this ratio is much lower. Regarding the Myxomycetes, the ratio is less than $30 \%$ for the total of 900 species currently accepted, although Brazil is the second country in the Neotropics and the first in South America in number of records (considering as yet that the species recorded in Pantanal and Pampa are still not included in the present dataset); for Chytridiomycota there is about $10 \%$ of the registered in the world, while for Zygomycota the proportion is less than 5\%, indicating the need for more experts and work dedicated to these groups.

The Ascomycota teleomorphs were initially more addressed in studies of leaf fungi by Batista et al. (Silva \& Minter 1995; Batista 2015), and are now being investigated further by experts in plant pathology. As a highlight of the latest studies with teleomorphs are those performed with pathogenic, coprophilous and lichenized fungi. However, much of what has been recorded, especially in the Central-West and Southeast regions, has not yet been recorded in the present list. Ascomycota anamorphic were also a well studied group among leaf fungi and continue to be investigated under several aspects: taxonomic, ecological, phytopathological and biotechnological. A large portion of the taxa is as yet without a defined taxonomic position and they appear in insertae sedis groups in the present list.

In Brazil, few experts are dedicated to the Ascomycota, and, considering that this is the largest group of fungi, it is understandable the need for increasing specialized staff training. The Basidiomycota have more experts and, as many form macroscopic, often showy structures, are better studied and known. This group also includes the rusts, important parasites of plants, which have attracted the attention of a few researchers. For other phyla, the number of specialists is even smaller or nonexistent in Brazil and it is clear the need for training human resources in taxonomy in order to investigate and record the occurrence of the country's fungi. Some groups are barely known in Brazil as the Blastocladiomycota with 17 species recorded, Cryptomycota, Entomophthoromycota, Hyphochytriomycota, Labyrinthulomycota and Plasmodiophoromycota with five or fewer species.

The 2015 list includes 13 phyla (plus a taxonomic group placed as insertae sedis), 102 orders (another insertae sedis group), 1,246 genera and 5,719 species of fungi. These numbers represent a considerable increase when compared to 2010 , when 78 orders and 924 genera were recorded (Maia \& Carvalho Jr. 2010). Of the 102 orders, 41 belong to Ascomycota and 22 to Basidiomycota. In Ascomycota, the six orders with higher number of species are Xylariales (275 species), Asterinales (248) Lecanorales (219), Ostropales (162) Microthyriales (120) and Capnodiales (99) (Tab. 2). In Basidiomycota, the orders with higher species numbers are Agaricales (927 species), Pucciniales (750) Polyporales (453), Hymenochaetales (166), Russulales (137) and Boletales (92) (Tab. 2). 


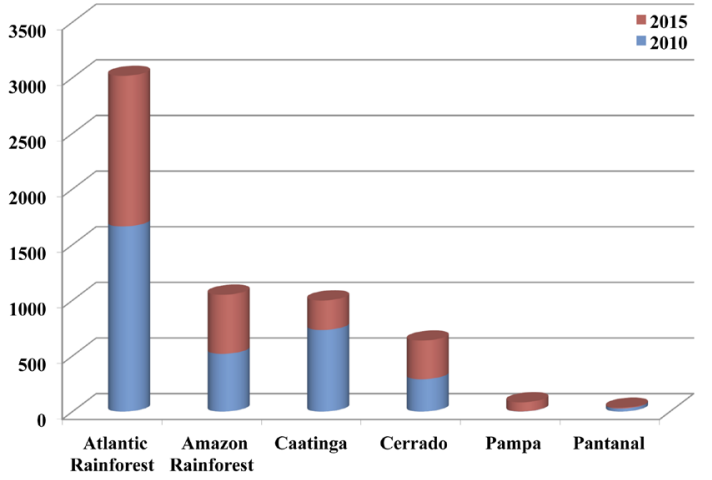

Figure 1 - Increase in the number of species registered in the Brazilian phythogeographical domains from 2010 to 2015.

Table 2 - Increase in the number of species recorded in the six more representative Orders of Ascomycota and Basidiomycota in the Brazilian List of Plants and Fungi comparing 2010 with 2015.

\begin{tabular}{lcc}
\hline Phylum/Ordem & Number of fungal species \\
\hline & $\mathbf{2 0 1 0}$ & $\mathbf{2 0 1 5}$ \\
\hline Ascomycota & 1134 & 1881 \\
Xylariales & 213 & 275 \\
Asterinales & 0 & 248 \\
Lecanorales & 67 & 219 \\
Ostropales & 155 & 162 \\
Microthyriales & 0 & 120 \\
Capnodiales & 4 & 99 \\
Basidiomycota & 1730 & 2741 \\
Agaricales & 255 & 927 \\
Pucciniales & 729 & 750 \\
Polyporales & 333 & 453 \\
Hymenochaetales & 136 & 166 \\
Russulales & 46 & 137 \\
Boletales & 86 & 92 \\
\hline
\end{tabular}

Most of the fungi mentioned in the current list are saprobes, but parasites and symbionts also stand out. Among the plant parasitic species, rusts (Pucciniales) are the second order better represented among the Basidiomycota and among the Ascomycota the second order with more records is Asterinales. Microthyriales and Capnodiales, with a significant number of species already listed, also add many plant pathogenic species. Other groups,

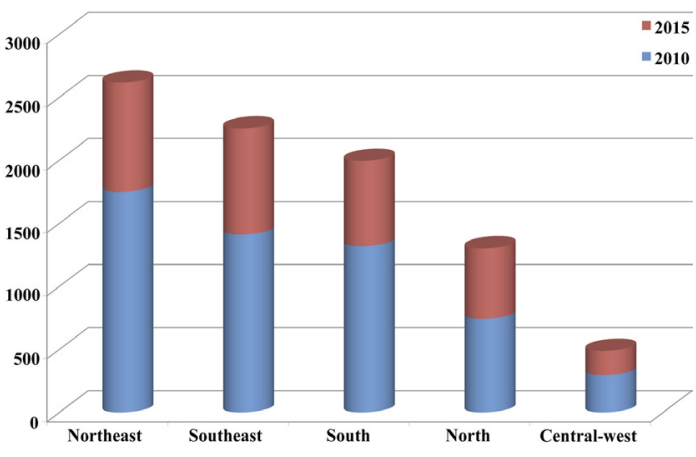

Figure 2 - Number of fungal species recorded in each Brazilian region in 2010 and 2015.

Table 3 - Distribution of the 21 richest genera of fungi in number of species recorded in the first version of the Brazilian List of Plants and Fungi (Maia \& Carvalho Jr. 2010) and the current number (2015).

\begin{tabular}{|c|c|c|}
\hline \multirow[t]{2}{*}{ The richest Generaof fungi } & \multicolumn{2}{|c|}{$\begin{array}{c}\text { Number of fungal } \\
\text { species }\end{array}$} \\
\hline & 2010 & 2015 \\
\hline Puccinia & 252 & 256 \\
\hline Marasmius & 2 & 128 \\
\hline Xylaria & 91 & 121 \\
\hline Cladonia & 0 & 113 \\
\hline Uromyces & 102 & 103 \\
\hline Lepiota & 10 & 98 \\
\hline Uredo & 73 & 75 \\
\hline Asterina & 0 & 73 \\
\hline Aecidium & 67 & 67 \\
\hline Scolecopeltidium & 0 & 65 \\
\hline Asteridiella & 1 & 53 \\
\hline Phellinus & 48 & 53 \\
\hline Physarum & 50 & 52 \\
\hline Glomus & 43 & 47 \\
\hline Ravenelia & 43 & 43 \\
\hline Pythium & 41 & 41 \\
\hline Pluteus & 6 & 39 \\
\hline Lembosia & 0 & 38 \\
\hline Penicillium & 37 & 38 \\
\hline Entoloma & 9 & 37 \\
\hline Prospodium & 30 & 37 \\
\hline Total & 905 & 1577 \\
\hline
\end{tabular}


such as Oomycota and Plasmodiophoromycota are also represented by several species that attack plants. Equally important is to record symbionts, consisting of lichens, or lichenized fungi (most Ascomycota, mainly represented by Lecanorales) and mycorrhizal species (all orders of Glomeromycota, several Basidiomycota and a few Ascomycota and Zygomycota, specifically Endogonales).

The distribution of the 21 richest genera of fungi in number of species recorded in 2010 and the comparison with the current number is presented in Table 3. There was no significant increase in the number of species in some genera such as Puccinia, Uromyces and Uredo because the vast majority of records of these taxa in the country was already included in the former edition of the list (Maia \& Carvalho 2010). Conversely, previously not recorded Asterina and Cladonia passed respectively to 73 and 113 recorded species, and Marasmius increased from two species to 128 species records in the country. This increase is due to the participation of more experts who accepted the invitation to contribute to the list between 2010 and 2015, to the study of some taxa such as Marasmius, a genus revised during this period, to the discovery of new species to science, to new collections being carry out in areas previously poorly studied (as the lichens in Roraima, for example), and due to an increase in the species records already known for Brazil, with expansion of the known geographical distribution. Thus, the inclusion of genera and species that had not yet been recorded in 2010 led to changes in classification of the richest genera, resulting in a new configuration.

The Atlantic Rainforest, increasing in 1,353 species since 2010 and currently with 3,017 species recorded, remains the better known and most investigated biome. On the other hand, the Amazon Rainforest increased in 531 species since 2010 , currently with 1,050 species, surpassing the number of species records from the Caatinga, which has 999 taxa. The Cerrado, currently with 638 records has increased 347 species since 2010 . Pampa currently with 84 and Pantanal with 35 species of fungi also reversed the positions compared to 2010 (Fig. 1).

The Northeast region remains on the lead in terms of number of records, totalling 2,617 species, followed by the Southeast $(2,252)$, South $(1,995)$, North $(1,301)$ and Central-West (488), each of these regions were increased by
$868,841,675,558$ and 192 respectively since 2010 (Fig. 2). Regarding the distribution of the fungi in the Brazilian states, there was a significant contribution of the number of species compared to 2010 (Tab. 4) and highlight is given to the number of records for São Paulo and Pernambuco, followed by Rio Grande do Sul, Bahia, Amazonas, Paraná and Santa Catarina.

Table 4 - Number of fungal species, lato sensu and stricto sensu, by State (in descending order of records) in the first version of the Brazilian List of Plants and Fungi (Maia \& Carvalho Jr. 2010), and the current number (2015).

\begin{tabular}{lcc}
\hline States & Number of fungal species \\
\hline & $\mathbf{2 0 1 0}$ & $\mathbf{2 0 1 5}$ \\
\hline São Paulo & 1161 & 1846 \\
Pernambuco & 937 & 1611 \\
Rio Grande do Sul & 856 & 1377 \\
Bahia & 584 & 876 \\
Amazonas & 408 & 802 \\
Paraná & 529 & 761 \\
Santa Catarina & 482 & 700 \\
Rio de Janeiro & 443 & 678 \\
Minas Gerais & 399 & 601 \\
Pará & 302 & 442 \\
Paraíba & 261 & 441 \\
Alagoas & 290 & 320 \\
Roraima & 75 & 292 \\
Sergipe & 215 & 245 \\
Ceará & 106 & 213 \\
Rio Grande do Norte & 148 & 202 \\
Piaú́ & 139 & 193 \\
Roraima & 75 & 183 \\
Mato Grosso & 135 & 180 \\
Maranhão & 52 & 173 \\
Goiás & 104 & 165 \\
Distrito Federal & 77 & 161 \\
Amapá & 88 & 154 \\
Mato Grosso do Sul & 82 & 122 \\
Acre & 61 & 106 \\
Espírito Santo & 45 & 92 \\
Tocantins & 5 & 25 \\
\hline & & \\
& & \\
& &
\end{tabular}


With smaller representation of fungi are, in descending order: Goiás, Amapá, Mato Grosso do Sul, Acre, Tocantins and Espírito Santo.

The records for Tocantins are from recent collections. Older samplings are possible registered for the state of Goiás, of which Tocantins was a part until 1988. These states of the Central-West region need to be more investigated to survey their mycota. The Federal District also has few records of fungi (about 160), although mycologists at the University of Brasilia have been working in the region in recent decades. This indicates that much of what is studied is not available in the virtual herbarium and that we need a greater effort of mycologists to join the community that worked in the presently list, including the fungi identified during their taxonomic studies. Table 4 shows that, compared to 2010 , there was a significant contribution of the number of fungal species registered in all federal units.

\section{Conclusions}

The great effort made by mycologists in the last five years resulted in increased completeness of the Fungal list in 2015. Despite the hard work of mycologists, the reality is that, as already highlighted by Maia \& Carvalho Jr. (2010), the information available derives from samples collected in regions where there are more active groups of mycologists. For certain Brazilian states such as Tocantins, data are practically non-existent. Relevant contribution was recently given by Marcela Cáceres group, who investigated lichenized fungi in Rondônia, adding 104 new records for the state, of which 75 are new to science (Aptroot \& Cáceres 2014a, 2014b; Cáceres et al. 2014a, 2014b, 2014c). This example highlights the potential for mycological studies and demonstrates that much field and laboratory work must still be carried out to obtain a closer estimate of the number of species of Brazilian fungi.

Despite the significant increase in the number of occurrence records of fungi for Brazil in the last five years, the number of cited species does not reflect the totality of what potentially exists in the country. Several publications, among which state lists (Maia et al. 2002; Meijer 2008); regional lists (Gusmão \& Maia 2006) and general lists (Putzke 1994; Mendes et al. 1998, 2010.), where approximately 7,000 taxa are mentioned could not be fully incorporated at the moment, among other reasons due to limitations of staff and time. Numerous fungal records in herbaria and culture collections are not yet recorded within this list, and these collections are important sources of information that should be included in subsequent editions.

Considering the latest estimates that quote 5.1 million of fungal species worldwide (Blackwell 2011) and that, by 2008, slightly less than 100,000 species were described (Kirk 2008), the current knowledge approaches $2 \%$ of the estimated diversity of the group. It appears that, despite the efforts and the information that may be included in future projects, there is still a long way to go in terms of developing a basic knowledge of the diversity of the Brazilian mycota.

The database of fungi from the 2015 list is still preliminary, but it represents a rare opportunity to increase the effective systematization of data that were scattered in various publications and to provide information on the fungi that occur in the country. To increase knowledge about the occurrence and distribution of this important group of organisms we need the help of a vast number of mycologists, to intensify inventories, taxonomic studies and training of specialized human resources to cover the insufficiently surveyed areas, which are numerous, and disseminate more effectively the mycological knowledge.

\section{Acknowledgements}

We thank our botanical colleagues, for the opportunity to participate, that allowed the inclusion of fungi in this project. Paula Leitman and Fabiana Luiza Ranzato Filardi, for their patience and dedicated assistance. Special thanks are due to $\mathrm{CNPq}$, which has funded research that underlie the data analysed here through various projects (Protax, Reflora, Sisbiota, Universal, INCT-Herbário Virtual and others).

\section{References}

Abrahão, M.C.; Gugliotta, A.M. \& Bononi, V.L.R. 2012. Xylophilous Agaricomycetes (Basidiomycota) of the Brazilian Cerrado. Check List 8: 1102-1116.

Almeida, D.A.C.; Izabel, T. dos S.S.\& Gusmão, L.F.P. 2011. Fungos conidiais do Bioma Caatinga. I. Novos registros para o Continente americano, Neotrópico, América do Sul e Brasil. Rodriguesia 62: 43-53.

Almeida, D.A.C.; Cruz, A.C.R.; Marques, M.F.O. \& Gusmão, L.F.P. 2013. Conidial fungi from semiarid Caatinga biome of Brazil. New and interesting Zanclospora species. Mycosphere Online - Journal of Fungal Biology 4: 684-692. 
Almeida, D.A.C. \& Gusmão, L.F.P. 2014. Ypsilomyces, a new thallic genus of conidial fungi from the semi-arid Caatinga biome of Brazil. Mycotaxon 129: 181-186,

Almeida, D.A.C.; Gusmão, L.F.P. \& Miller, A.N. 2014. A new genus and three new species of hysteriaceous ascomycetes from the semiarid region of Brazil. Phytotaxa 176: 298-308.

Alves, M.H.; Costa, A.A.A. \& Cavalcanti, L.H. 2010. Myxomycetes, state of Ceará, northeastern Brazil. Check List 6: 555-558.

Alves, M.M.E.; Aptroot, A.; Lacerda, S.R. \& Cáceres, M.E S. 2014. A new Eschatogonia species and two new Gassicurtia species from Chapada do Araripe, Ceará, NE Brazil. The Bryologist 117: 50-53.

Aptroot, A.; Ertz, D.; Lima, E.L.; Jesus, K.A.; Maia, L.C. \& Cáceres, M.E.S. 2013. Two new species of Roccellaceae (Ascomycota: Arthoniales) from Brazil, with the description of the new genus Sergipea. The Lichenologist 45: 627-634.

Aptroot, A. \& Cáceres, M.E.S. 2014a. New lichen species from termite nests in rainforest in Brazilian Rondônia and adjacent Amazonas. Lichenologist 46: 365-372.

Aptroot, A. \& Cáceres, M.E.S. 2014b. A key to the corticolous microfoliose, foliose and related crustose lichens from Rondônia, Brazil, with the description of four new species. Lichenologist 46: 783-799.

Aptroot, A. \& Cáceres, M.E.S. 2014c. A refined species concept in the tropical lichen genus Polymeridium (Trypetheliaceae) doubles the number of known species, with a worldwide key to the species. Nova Hedwigia 98: 1-29.

Baltazar, J.M. \& Gibertoni, T.B. 2009. A checklist of the aphyllophoroid fungi (Basidiomycota) recorded from the Brazilian Atlantic Forest. Mycotaxon 109: 439-442.

Baltazar, J.M. \& Gibertoni, T.B. 2010. New combinations in Phellinus s.l. and Inonotus s.1. Mycotaxon 111: 205-208.

Baltazar, J.M.; Ryvarden, L. \& Gibertoni, T.B. 2010. The genus Coltricia in Brazil: new records and two new species. Mycologia 102: 1253-1262.

Baltazar, J.M.; Drechsler-Santos, E.R.; Ryvarden, L.; Cavalcanti, M.A.Q. \& Gibertoni, T.B. 2012. Contribution to the knowledge of polypores (Agaricomycetes) from the Atlantic Forest and Caatinga, with new records from Brazil. Mycosphere Online - Journal of Fungal Biology 3: 267-280.

Baltazar, J.M.; Ryvarden, L. \& Gibertoni, T.B. 2013. Diplomitoporus (Polyporales, Basidiomycota) in Brazil revisited. Mycological Progress 13: 313-319.

Barbosa, F.R. \& Gusmão, L.F.P. 2011. Conidial fungi from the semi-arid Caatinga biome of Brazil. Rare freshwater hyphomycetes and other new records. Mycosphere 2: 475-485.
Barbosa, F.R.; Raja, H.A.; Shearer, C.A. \& Gusmão, L.F.P. 2013. Some freshwater fungi from the Brazilian Semi-Arid Region, including two new species of Hyphomycetes. Cryptogamie. Mycologie 34: 243-258.

Barbosa, F.R.; Machiner, M.; Barbosa, G.C.K. \& Gusmão, L.F.P. 2014. A checklist of the fungi recorded from Serra da Jibóia, Bahia state, Brazil. Mycotaxon 129: 485-485.

Batista, A.C. 2015. Publicações. Available in <http:// batista.fungibrasil.net/>. Access on 6 May 2015.

Bezerra, A.C.C. \& Cavalcanti, L.H. 2010. Diderma albo-columella (Myxomycetes) a new species in the Brazilian Atlantic Forest. Rodriguesia 61: 105-108.

Bezerra, M.F.; Farias, G.B. \& Cavalcanti, L.H. 2010. Mixobiota do Parque Nacional Serra de Itabaiana, SE, Brasil: Trichiales. Acta Botanica Brasilica 24: 510-517.

Bezerra, A.C.C.; Lima, V.X.; Tenório, J.C.G \& Cavalcanti, L.H. 2014. Myxomycetes from Alagoas state (Brazil) and notes on its distribution. Biotemas 27: $13-22$.

Blackwell, M. 2011. The Fungi: 1, 2, 3 ... 5.1 million species? American Journal of Botany 98: 426-438.

Cabral, T.S.; Marinho, P.; Goto, B.T. \& Baseia, I.G. 2012. Abrachium, a new genus in the Clathraceae, and Itajahya reassessed. Mycotaxon 119: 419-429.

Cáceres, M.E.S.; Vieira, T.S.; Jesus, L.S. \& Lücking, R. 2012. New and interesting lichens from the Caxiuanã National Forest in the Brazilian Amazon. Lichenologist 44: 807-812.

Cáceres, M.E.S.; Santos, V.M.; Góes, D.T.; Mota, D.A. \& Aptroot, A. 2013. Two new species of Malmidea from north-eastern Brazil. Lichenologist 45: 619-622.

Cáceres, M.E.S.; Aptroot, A. \& Parnmen, S. 2014a. Remarkable diversity of the lichen family Graphidaceae in the Amazon rain forest of Rondônia, Brazil. Phytotaxa 189: 87-136.

Cáceres, M.E.S.; Ertz, D. \& Aptroot, A. 2014b. New species and interesting records of Arthoniales from the Amazon, Rondônia, Brazil. Lichenologist 46: 573-588.

Cáceres, M.E.S.; Lima, E.L.; Aptroot, A. \& Lücking, R. 2014c. Liquens brasileiros: novas descobertas evidenciam a riqueza no Norte e Nordeste do país. Boletim do Museu de Biologia Mello Leitão 35: 101-119.

Calaça, F.J.S.; Silva, N.C. \& Xavier-Santos, S. 2014. A checklist of coprophilous fungi and other fungi recorded on dung from Brazil. Mycotaxon 128: 205-205.

Carmo, L.T.; Monteiro, J.S.; Gusmão, L.F.P.; Sotão, H.M.P.; Gutierres, A.H. \& Ruiz, R.F.C. 2014. Anabahusakala, a new genus from the Brazilian Amazon rainforest. Mycotaxon 127: 11-15. 
Carvalho Jr., A.A. \& Hennen, J.F. 2010. New species and nomenclature in Prospodium (Uropyxidaceae, Pucciniales) and the new anamorphic genus Canasta in the Neotropics. Mycologia 102: 1096-1113.

Carvalho Jr., A.A. \& Hennen, J.F. 2012. The species of Puccinia on Piptocarpha and Vanillosmopsis in the Neotropics. Mycologia 104: 557-568.

Cavalcanti, L.H. 2002. Biodiversidade e distribuição de mixomicetos em ambientes naturais e antropogênicos no Brasil: espécies ocorrentes nas Regiões Norte e Nordeste. In: Araujo, E.L. et al. (eds.). Biodiversidade, conservação e uso sustentável da flora do Brasil. Universidade Federal Rural de Pernambuco, Sociedade Botânica do Brasil, Recife. Pp. 209-216.

Cavalcanti, L.H.; Ponte, M.P.P. \& Mobin, M. 2006. Myxomycetes, State of Piauí, Northeast Brazil. Check List 2: 70-74.

Cavalcanti, L.H.; Damasceno, G.; Bezerra, A.C.C. \& Costa, A.A.A. 2014. Mangrove myxomycetes: species occurring on Conocarpus erectus L. (Combretaceae). Sydowia 66: 183-190.

Cavalcanti, L.H.; Costa, A.A.A.; Barbosa, D.I.; Agra, L.A.N.N. \& Bezerra, A.C.C. 2015. Distribution and occurrence of Oligonema (Trichiales, Myxomycetes) in Brazil. Brazilian Journal of Botany 38:187-191.

Coimbra, V.R.M. \& Gibertoni, T.B. 2015. First record of Trichopilus fasciculatus (Agaricales) from Brazil, with a key for the species of Entolomataceae from the Northern region. Mycoscience 56: 118-122.

Coimbra, V.R.M.; Gibertoni, T.B. \& Wartchow, F. 2012. Phaeocollybia nigripes (Agaricomycetes), a new species from Brazil. Mycotaxon 120: 171-179.

Coimbra, V.R.M.; Gibertoni, T.B. \& Wartchow, F. 2013. Megacollybia rimosa (Agaricales), a new species from Brazil. Mycoscience 54: 206-209.

Cortez, V.G.; Baseia, I.G. \& Silveria, R.M.B. 2011. Two noteworthy Phallus from southern Brazil. Mycoscience (Tokyo) 52: 436-438.

Costa, A.A.A.; Ferreira, I.N.; Bezerra, M.F.A. \& Cavalcanti, L.H. 2011. Mixobiota de Floresta Atlântica: novas referências de Physarales para o estado da Paraíba, Nordeste do Brasil. Revista Brasileira de Botânica 34: 177-185.

Costa, A.A.A.; Bezerra, A.C.C.; Lima, V.X. \& Cavalcanti, L.H. 2014. Diversity of Myxomycetes in an environmentally protected area of Atlantic Forest in northeastern Brazil. Acta Botanica Brasílica 28: 345-455.

Cruz, A.C.R.; Gusmão, L.F.P.; Castaneda Ruiz, R.F.; Stadler, M. \& Minter, D.W. 2012. Zelodactylaria, an interesting new genus from semi-arid northeast Brazil. Mycotaxon 119: 241-248.

Curvo, R.J.C. 2006. Breve histórico da micologia e fungos referidos para Mato Grosso - Brasil. Revista Profiscientia 3: 15-21.
Damasceno, G.; Tenório, J.C.G.; Cavalcanti, L. H. \& Andrade, L.H.C. 2011. Stemonitaceae (Myxomycetes) in Brazilian mangroves. Sydowia 63: 9-22.

Drechsler-Santos, E.R.; Gibertoni, T. B.; Goes-Neto, A.; Cavalcanti, M.A.Q. 2009. A re-evaluation of the lignocellulolytic Agaricomycetes from the Brazilian semi-arid region. Mycotaxon 108: 241-244.

Drechsler-Santos, E.R.; Cavalcanti, M.A.Q.; LoguercioLeite, C. \& Robledo, G. 2012a. On Neotropical Daedalea species: Daedalea ryvardenica sp. nov. Kurtziana 37: 65-72.

Drechsler-Santos, E.R.; Wartchow, F.; Coimbra, V.R.M.; Gibertoni, T.B. \& Cavalcanti, M.A.Q. 2012 b. Studies on lentinoid fungi (Lentinus and Panus) from the semi-arid region of Brazil. The Journal of the Torrey Botanical Society 139: 437-446.

Drechsler-Santos, E.R.; Wartchow, F.; Coimbra, V.R.M.; Gibertoni, T.B. \& Cavalcanti, M.A.Q. 2012c. Studies on lentinoid fungi (and) from the semi-arid region of Brazil. The Journal of the Torrey Botanical Society 139: 437-446.

Drechsler-Santos, E.R.; Ryvarden, L.; Bezerra, J.L.; Gibertoni, T.B.; Salvador-Montoya, C.A. \& Cavalcanti, M.A.Q. 2013. New Records of Auriculariales, Hymenochaetales and Polyporales (Fungi, Agaricomycetes) for the Caatinga Biome. Check List 9: 800-805.

Feuerstein, S.C.; Cunha-Dias, I.P.R.; Aptroot, A.; Eliasaro, S. \& Caceres, M.E.S. 2014. Three new Diorygma (Graphidaceae) species from Brazil, with a revised world key. Lichenologist 46: 753-761.

Fidalgo, O. 1968. Introdução à história da micologia brasileira. Rickia 3: 1-44.

Fiuza, P.O. \& Gusmão, L.F.P. 2013a. Ingoldian fungi from the semi - arid Caatinga biome of Brazil. Mycosphere Online - Journal of Fungal Biology 4: 1133-1150.

Fiuza, P.O. \& Gusmão, L.F.P. 2013b. Ingoldian fungi from semi-arid Caatinga biome of Brazil. The genus Campylospora. Mycosphere 4: 559-565.

Fiuza, P.O.; Gusmão, L.F.P.; Cruz, A.C.R. \& Ruiz, R.F.C. 2014. Conidial fungi from the semiarid Caatinga biome of Brazil: a new species of Pseudoacrodictys. Mycotaxon 127: 33-37.

Fiuza, P.O.; Ottoni-Boldrini, B.M.P.; Monteiro, J.S.; Catena, N.R.; Hamada, N. \& Gusmão, L.F.P. 2015. First records of Ingoldian fungi from the Brazilian Amazon. Brazilian Journal of Botany 38: 15

Forzza, R.C.; Baumgratz, J.F.A.; Bicudo, C.E.M.; Canhos, D.A.L.; Carvalho Jr., A.A.; Costa, A.F.; Costa, D.P.; Hopkins, M.; Leitman, P.M.; Lohmann, L.G.; Maia, L.C.; Martinelli, G.; Menezes, M.; Morim, M.P.; Nadruz-Coelho, M.A.; Peixoto, A.L.; Pirani, J.R.; Prado, J.; Queiroz, L.P.; Souza, V.C.; Stehmann, J.R.; Sylvestre, L.; Walter, B.M.T. \& Zappi, D. (eds.). 2010. Catálogo de plantas e fungos 
do Brasil. 2 vols. Andrea Jakobsson Estúdio / Jardim Botânico do Rio de Janeiro, Rio de Janeiro. 1699p.

Gibertoni, T.B. \& Drechsler-Santos, E.R. 2010. Lignocellulolytic Agaricomycetes from the Brazilian Cerrado biome. Mycotaxon 111: 87-90.

Gibertoni, T.B.; Drechsler-Santos, E.R.; Baltazar, J.M.; Gomes-Silva, A.C.; Nogueira-Melo, G.S.; Ryvarden, L. \& Cavalcanti, M.A.Q. 2011. The genus Trichaptum (Agaricomycetes, Basidiomycota) in Brazil. Nova Hedwigia 93: 85-96.

Gibertoni, T.B., Martins-Júnior, A., Ryvarden, L. \& Sotão, H. 2012. Oxyporus mollis sp. nov. (Agaricomycetes) from the Eastern Brazilian Amazonia. Nova Hedwigia 94: 175-179.

Gibertoni, T.B. \& Ryvarden, L. 2014. Studies in Neotropical polypores 36 . A note on the genus Henningsia. Synopsis Fungorum 32: 55-57.

Goes Neto, A. \& Cavalcanti, L.H. 2002. Myxomycetes of the State of Bahia: historical review and current situation. Mycotaxon 82: 335-342.

Gomes-Silva, A.C.; Ryvarden, L. \& Gibertoni, T.B. 2012. Two new species of Phellinus s.1. from the Brazilian Amazonia. Phytotaxa 67: 55-60.

Gomes-Silva, A.C.; Ryvarden, L. \& Gibertoni, T.B. 2013. Inonotus amazonicus sp. nov., I. calcitratus comb. nov. and notes on Phylloporia (Hymenochaetaceae, Agaricomycetes) from the Brazilian Amazonia. Mycoscience 54: 116-121.

Gomes-Silva, A.C.; Medeiros, P.S.; Soares, A.M.S.; Sotão, H.M.P.; Ryvarden, L. \& Gibertoni, T.B. 2014. Two new species of Rigidoporus (Agaricomycetes) from Brazil and new records from the Brazilian Amazonia. Phytotaxa 156: 191-200.

Goto, B.T.; Silva, G.A.; Yano-Melo, A.M. \& Maia, L.C. 2010. Checklist of the arbuscular mycorrhizal fungi (Glomeromycota) in the Brazilian semiarid. Mycotaxon 113: 251-254.

Goto, B.T.; Silva, G.A.; Maia, L.C.; Souza, R.G.; Coyne, D.; Tchabi, A.; Lawouin, L.; Hountondji, F. \& Oehl, F. 2011. Racocetra tropicana, a new species in the Glomeromycetes from tropical areas. Nova Hedwigia 92: 69-82.

Goto, B.T.; Silva, G.A.; Assis, D.M.A.; Silva, D.K.A.; Souza, R.G.; Ferreira, A.C.A.; Jobim, K.; Mello, C.M.A.; Vieira, H.E.E.; Maia, L.C. \& Oehl, F. 2012. Intraornatosporaceae (Gigasporales), a new family with two new genera and two new species. Mycotaxon 119: 117-132.

Goto, B.T.; Araújo, A.F.; Soares, A.C.F.; Ferreira, A.C.A.; Maia, L.C.; Sousa, C.S. \& Silva, G.A. 2013. Septoglomus titan, a new fungus in the Glomeraceae (Glomeromycetes) from Bahia, Brazil. Mycotaxon 124: 101-109.

Gusmão, L.F.P. \& Maia, L.C. 2006. (eds.). Diversidade e caracterização dos fungos do semi-árido brasileiro. Vol. 2. Instituto do Milênio do Semi-árido. MCT/ Associação Plantas do Nordeste, Recife. 219p.
Hennen, J.F.; Figueiredo, M.B.; Carvalho Jr., A.A. \& Hennen, P.G. 2005. Catalogue of the species of plant rust fungi (Uredinales) of Brazil. Jardim Botânico do Rio de Janeiro, Rio de Janeiro. 490p.

Hibbett, D.S.; Binder, M.; Bischoff, J.F.; Blackwell, M.; Cannon, P.F.; Eriksson, O.E.; Huhndorf, S.; James, T.; Kirk, P.M.; Lücking, R.; Lumbsch, H.T.; Lutzoni, F.; Matheny, P.B.; McLaughlin, D.J.; Powell, M.J.; Redhead, S.; Schoch, C.L.; Spatafora, J.W.; Stalpers, J.A.; Vilgalys, R.; Aime, M.C.; Aptroot, A.; Bauer, R.; Begerow, D.; Benny, G.L.; Castlebury, L.A.; Crous, P.W.; Daí, Y.C.; Gams, W.; Geiser, D.M.; Griffith, G.W.; Gueidan, C.; Hawksworth, D.L.; Hestmark, G.; Hosaka, K.; Humber, R.A.; Hyde, K.D.; Ironside, J.E.; Köljalg, U.; Kurtzman, C.P.; Larsson, K.H.; Lichtwardt, R.; Longcore, J.; Miadlikowska, J.; Miller, A.; Moncalvo, J.M.; Mozley-Standridge, S.; Oberwinkler, F.; Parmasto, E.; Reeb, V.; Rogers, J.D.; Roux, C.; Ryvarden, L.; Sampaio, J.P.; Schüssler, A.; Sugiyama, J.; Thorn, R.G.; Tibell, L.; Untereiner, W.A.; Walker, C.; Wang, Z.; Weir, A.; Weiss, M.; White, M.M.; Winka, K.; Yao, Y.J. \& Zhang, N. 2007. A higher-level phylogenetic classification of the Fungi. Mycological Research 111:509-47.

Hochgesand, E. \& Gottsberger, G. 1996. Myxomycetes from State of São Paulo. Boletim do Instituto de Botânica 10: 1-46.

Hoffmann, K.; Voigt, K. \& Kirk, P.M. 2011. Mortierellomycotina subphyl. nov., based on multi-genes genealogies. Mycotaxon 115: 353-363.

Humber, R.A. 2012. Entomophthoromycota: a new phylum and reclassification for entomophthoroid fungi. Mycotaxon 120: 477-492.

Izabel, T.S.S.; Santos, D.; Almeida, D.A.C. \& Gusmão, L.F.P. 2011. Fungos conidiais do Bioma Caatinga. II. Novos registros para o Continente americano, Neotrópico e América do Sul e Brasil. Rodriguesia 62: 229-240.

Izabel, T.S.S.; Cruz, A.C.R. \& Gusmão, L.F.P. 2013. Conidial fungi from the semi-arid Caatinga biome of Brazil. Ellisembiopsis gen. nov., new variety of Sporidesmiella and some notes of Sporidesmium complex. Mycosphere Online - Journal of Fungal Biology 4: 156-163.

Jesus, A.L.; Marano, A.V.; Schoenlein-Crusius, I.H. \& Pires-Zottarelli, C.L.A. 2013. Diversidade de organismos zoospóricos do córrego Pirarungaua, Parque Estadual das Fontes do Ipiranga, São Paulo, Brasil: novas citações. Hoehnea 40: 167-180.

Kirk, P.; Cannon, P.F.; Minter, D.W. \& Stalpers, J.A. 2008. $10^{\mathrm{a}}$ ed. Dictionary of Fungi. CABI Publishing, Wallinford. 771p.

Lima, E.L.; Maia, L.C.; Aptroot, A. \& Cáceres, M.E.S. 2013a. New lichen species from Vale do Catimbau, Pernambuco, Brazil. The Bryologist 116: 327-329.

Lima, E.L.; Mendonça, C.O.; Maia, L.C.; Aptroot, A. \& Cáceres, M.E.S. 2013b. Two new species of 
Pyrenula with a red or orange thallus from Vale do Catimbau National Park, Pernambuco, Brazil. Lichenologist 45: 199-202.

Maia, L.C.; Melo, A.M.Y. \& Cavalcanti, M.A. 2002. Diversidade de fungos no estado de Pernambuco. In: Tabarelli, M. \& Silva, J.M.C. da (orgs.). Diagnóstico da Biodiversidade de Pernambuco. Vol. 1. Editora Massangana, Recife. Pp. 15-50.

Maia, L.C.; Drechsler-Santos E.R. \& Cáceres, M. 2007. Representatividade dos fungos nos herbários brasileiros. In: Maia, L.C.; Malosso, E. \& Yano-Melo, A.M. (orgs.). Micologia: avanços no conhecimento. Universitária da UFPE, Recife. Pp. 189-194.

Maia, L.C. \& Carvalho Jr., A.A. 2010. Fungos do Brasil. In: Forzza, R.C. et al. (orgs.). Catálogo de plantas e fungos do Brasil. Vol.1. Andrea Jakobsson Estúdio /Instituto de Pesquisas Jardim Botânico do Rio de Janeiro, Rio de Janeiro. Pp. 43-48.

Maia, L.C.; Silva, G.A.; Yano-Melo, A.M. \& Goto, B.T. 2010. Fungos micorrízicos arbusculares no bioma Caatinga. In: Siqueira, J.O.; de Souza, F.A.; Cardoso, E.J.B.N. \& Tsai, S.M. (orgs.). Micorrizas: 30 anos de pesquisas no Brasil. Vol. 1. Editora UFLA, Lavras. Pp. 311-339.

Maimoni-Rodella, R.C. 2002. Biodiversidade e distribuição de mixomicetos em ambientes naturais e antropogênicos no Brasil: espécies ocorrentes nas Regiões Sudeste e Centro-Oeste. In: Araujo, E.L. et al. (eds.). Biodiversidade, conservação e uso sustentável da flora do Brasil. Universidade Federal Rural de Pernambuco, Sociedade Botânica do Brasil, Recife. Pp. 217-220.

Marinho, F.; Silva, G.A.; Ferreira, A.C.A.; Veras, J.S.N.; Souza, N.M.F.; Goto, B.T.; Maia, L.C. \& Oehl, F. 2014. Bulbospora minima, a new genus and a new species in the Glomeromycetes from semi-arid Northeast Brazil. Sydowia 66: 313-323.

Meijer, A.A.R. 2008. Macrofungos Notáveis das Florestas de Pinheiro-do-Paraná. Embrapa, Colombo. 431p.

Mello, C.M.A.; Silva, G.A.; Vieira, H.E.E.; Silva, I.R.; Maia, L.C. \& Oehl, F. 2012. Fuscutata aurea, a new species in the Glomeromycetes from cassava and maize fields in the Atlantic rainforest zone of Northeastern Brazil. Nova Hedwigia 95: 267-275.

Mello, C.M.A.; Silva, G.A.; Assis, D.M.A.; Pontes, J.S.; Ferreira, A.C.A.; Leão, M.P.C.; Vieira, H.E.E.; Maia, L.C. \& Oehl, F. 2013. Paraglomus pernambucanum sp. nov. and Paraglomus bolivianum comb. nov., and biogeographic distribution of Paraglomus and Pacispora. Journal of Applied Botany and Food Quality 86: 113-125.

Melo, R.F.R.; Miller, A.N.; Santiago, A.L.C. \& Maia, L.C. 2014. The genera Ascobolus and Saccobolus (Ascobolaceae, Pezizales) in Brazil. Mycosphere Online - Journal of Fungal Biology 5: 790-804.

Mendes, M.A.S.; Ferreira, M.A.S.V.; Dianese, J.C.; Santos, C.E.N.; Urben, A.F. \& Castro, C. 1998.
Fungos em Plantas no Brasil. Embrapa-SPI/EmbrapaCenargen, Brasília, DF. 569p.

Mendes, M.A.S.; Urbem, A.F. \& Dianese, J.C. 2010. Fungos em plantas no Brasil. Vol. 1. 2a ed. Embrapa, Brasília. 978p.

Menezes, A.A.; Lima, E.L.; Leite, A.B.X.; Maia, L.C.; Aptroot, A. \& Cáceres, M.E.S. 2013. New species of Arthoniales from NE Brazil. Lichenologist 45: 611-617.

Menolli Jr., N.; Breternitz, B.S. \& Capelari, M. 2014. The genus Pleurotus in Brazil: a molecular and taxonomic overview. Mycoscience 55: 378-389.

Milanez, A.I.; Pires-Zotarelli, C.L.A. \& Gomes, A.L. 2007. Brazilian zoosporic fungi. Seção de Micologia/ IBt, São Paulo. 112p.

Monteiro, J. S. \& Gusmão, L.F.P. 2013. An emendation of Fusticeps and two new species from the Brazilian Amazon Forest. Mycotaxon 123: 431-437.

Monteiro, J.S.; Gusmão L.F.P. \& Ruiz, R.F.C. 2014a. Helicodochium, a new microfungus from submerged wood in Brazil. Mycotaxon 127: 5-9.

Monteiro, J.S.; Gusmão, L.F.P. \& Ruiz, R.F.C. 2014 b. Two new microfungi from Brazilian Amazon Forest: Atrogeniculata submersa and Nigrolentilocus amazonicus. Mycotaxon 127: 39-45.

Nascimento, C.A.; Gomes, E.P.C.; Souza, J.I. \& PiresZottarelli, C.L.A. 2012. Zoosporic true fungi and heterotrophic straminipiles assemblages from soil of Brazilian Cerrado areas. Fungal Ecology 5: 114-123.

Neves, M.A.; Baseia, I.G.; Drechsler-Santos, E.R. \& Góes-Neto, A. 2013. Guide to the common fungi of the semiarid region of Brazil. TECC Editora, Florianópolis. 142p .

Oehl, F.; Silva, G.A.; Goto, B.T.; Maia, L.C. \& Sieverding, E. 2011a. Glomeromycota: two new classes and a new order. Mycotaxon 116: 365-379.

Oehl, F.; Silva, G.A.; Sanchez-Castro, I.; Goto, B.T.; Maia, L.C.; Vieira, H.E.E.; Barea, J.M. \& Sieverding, E. 2011b. Revision of Glomeromycetes with entrophosporoid and glomoid spore formation with three new genera. Mycotaxon 117: 297-316.

Parente, M.P.M. \& Cavalcanti, L.H. 2013. Myxomycetes on Palm Trees: Species on Attalea speciosa Mart. ex Spreng. Advances in Microbiology 3: 19-23.

Pontes, J.S.; Sánchez-Castro, I.; Palenzuela, J.; Maia, L.C.; Palenzuela, J.; Silva, G.A. \& Oehl, F. 2013. Scutellospora alterata, a new gigasporalean species from the semi-arid Caatinga biome in Northeastern Brazil. Mycotaxon 125: 169-181.

Putzke, J. 1994. Lista dos fungos Agaricales (Hymenomycetes, Basidiomycotina) referidos para Brasil. Caderno de Pesquisa, Série Botânica 6:1-189.

Putzke J. 2002. Myxomycetes na Região Sul do Brasil. In: Araujo, E.L. et al. (eds.). Biodiversidade, conservação e uso sustentável da flora do Brasil. Universidade Federal Rural de Pernambuco, Sociedade Botânica do Brasil, Recife. Pp. 221-223. 
Sá, M.C.A.; Pinheiro, F.G.B.; Silva, N.A.; Maia, L.C. \& Wartchow, F. 2014. Craterellus niger (Cantharellaceae, Cantharellales, Basidiomycota): a new species from Pernambuco, Brasil. Nova Hedwigia 99: 525-530.

Salazar-Yepes, M. \& Carvalho Jr., A.A. 2010a. Novos registros de ferrugens (fungi, Uredinales) para o Brasil, coletados no Parque Nacional do Itatiaia. Acta Botanica Brasilica 24: 378-385.

Salazar-Yepes, M. \& Carvalho Jr., A.A. 2010b. Ferrugens: diversidade de uredinales do Parque Nacional do Itatiaia, Brasil. Vol. 1. Technical Books, Rio de Janeiro. 201p.

Salazar-Yepes, M. \& Carvalho Jr., A.A. 2012. Caetea, a new genus of Pucciniales on Piptadenia (Fabaceae) from Brazil. Mycologia 104: 911-914.

Salazar-Yepes, M. \& Carvalho Jr., A.A. 2014. Two new rust species on Fabaceae from Brazil. Mycotaxon 128: 17-23.

Santiago, A.L.C.; Benny, G. \& Maia, L.C. 2011 a. Syncephalis aggregata-a new species from the semiarid region of Brazil. Mycologia 103: 135-138.

Santiago, A.L.C.M. de A.; Trufem, S.F.B.; Malosso, E.; Santos, P.J.F. \& Cavalcanti, M.A.Q. 2011 b. Zygomycetes from herbivore dung in the ecological reserve of Dois Irmãos, Northeast Brazil. Brazilian Journal of Microbiology 42: 89-95.

Santiago, A.L.C.M. de A.; Santos, P J.P. \& Maia, L.C. 2013. Mucorales from the semiarid of Pernambuco, Brazil. Brazilian Journal of Microbiology 44: 229-305.

Santiago, A.L.C.; Hoffmann, K.; Lima, D.X.; Oliveira, R.J.; Vieira, H.E.E.; Malosso, E.; Maia, L.C. \& Silva, G.A. 2014. Anew species of Lichtheimia (Mucoromycotina, Mucorales) isolated from Brazilian soil. Mycological Progress 13: 343-352.

Schüssler, A.; Schwarzott, D. \& Walker, C. 2001. A new fungal phylum, Glomeromycota: phylogeny and evolution. Mycological Research 105: 1413-1421.

Silva, M. \& Minter, D.W. 1995. Fungi from Brazil Recorded by Batista and Co-workers. Mycological Papers 169: 1-585.

Silva A.C.G. \& Gibertoni, T.B. 2009. Revisão do Herbário URM: novas ocorrências de Aphyllophorales para a Amazônia brasileira. Revista Brasileira de Botânica 32: 587-596.

Silva, C.F. \& Cavalcanti, L.H. 2010. Myxobiota of the Brazilian Atlantic Forest: species on oil palm tree (Elaeis guineensis, Arecaceae). Rodriguésia 61: 575-583.

Silva, N.A. \& Cavalcanti, L.H. 2012. Myxomycetes ocorrentes em áreas de Caatinga e Brejo de Altitude no sertão de Pernambuco, Brasil. Acta Botanica Brasilica 26: 901-915.
Silva, G.A.; Maia, L.C. \& Oehl, F. 2013. Phylogenetic systematics of the Gigasporales. Mycotaxon 122: 207-220.

Silva, C.R.; Castaneda-Ruiz, R.F. \& Gusmão, L.F.P. 2014. Anacraspedodidymum, a new genus from submerged wood in Brazil. Mycotaxon 128: 11-15.

Soares, A.M.S.; Sotão, H.M.P.; Medeiros, P.S. \& Gibertoni, T. 2014. Riqueza de fungos poliporoides (Agaricomycetes, Basidiomycota) em uma floresta ombrófila densa no Amapá, Amazônia brasileira. Boletim do Museu de Biologia Mello Leitao 35: 5-18.

Souza, J.I.; Pires-Zottarelli, C.L.A.; Santos, J.F.; Costa, J.P. \& Harakava, R. 2012. Isomucor (Mucoromycotina): a new genus from a Cerrado reserve in state of São Paulo, Brazil. Mycologia 104: 232-241.

Souza, J.I.; Marano, A.V.; Pires-Zottarelli, C.L.A.; Chambergo, F.S. \& Harakava, R. 2014. A new species of Backusella (Mucorales) from a Cerrado reserve in Southeast Brazil. Mycological Progress 13: 975-980.

Trierveiler-Pereira, L.; Calonge, F.D. \& Baseia, I.G. 2011. New distributional data on Geastrum (Geastraceae, Basidiomycota) from Brazil. Acta Botanica Brasilica 25: 577-585.

Viégas, A. P. 1939. Verticillium lecanii (Zimm.) n. comb., causador do halo branco do Coccus viridis (Green). Revista do Instituto de Café 25: 754-772.

Viégas, A.P. 1940. Môfo dos afídeos e aleirodídeos. Revista de Agricultura 15: 475-485.

Viégas, A.P. 1943. Alguns fungos do cerrado. Bragantia 3: 49-61.

Viégas, A.P. 1944. Alguns fungos do Brasil Ascomycetos. Bragantia 4: 1-392.

Viégas, A.P. 1945. Alguns fungos do Brasil - Cercospora. Boletim da Sociedade Brasileira de Agronomia 8: 1-160.

Viégas, A.P. 1946. Alguns fungos do Brasil. XIII Hifomicetos. Bragantia 6: 353-442.

Viégas, A.P. 1961. Índice de fungos da América do Sul. Campinas, Instituto Agronômico de Campinas. 921p.

Wartchow, F.; Maia, L.C. \& Cavalcanti, M.A. 2013a. Studies on Amanita (Agaricomycetidae, Amanitaceae) in Brazil: two yellow gemmatoid taxa. Nova Hedwigia 96: 61-71.

Wartchow, F.; Maia, L.C. \& Cavalcanti, M.A.Q. 2013b. Taxonomic studies of Amanita muscaria (L.) Lam (Amanitaceae, Agaricomycetes) and its infraspecific taxa in Brazil. Acta Botanica Brasilica 27: 31-39. 
